\title{
Postnatal Factors Associated With The Risk Of Stunting In Toddlers
}

\author{
Risa Nurhayati*, Dewi Indriani, Rahayu Budi Utami \\ STIKes Satria Bhakti Nganjuk, Indonesia \\ *ners.risa@gmail.com
}

\begin{abstract}
Stunting is a chronic nutritional problem characterized by short stature and related to the state of post natal. The WHO recommends stunting targets of less than $20 \%$ so as not to cause problems. Nganjuk regency is a prevalence district of stunting above 20. The purpose of this study is to find out the effect of postnatal factors on stunting events in Nganjuk Regency. The design of this study uses observational analytical research with case control design. Research site in Nganjuk Regency from May 15 to June 15, 2020. A sample of 450 toddlers was selected using fixed disease sampling which included a case group of 150 toddlers with stunting and a control group of 300 normal toddlers who were not in stunting, wasting and overweight conditions. The independent variables of this study are birth weight, birth length, exclusive breastfeeding and history of infectious diseases, while dependent variables research stunting cases. The data collection tool uses questionnaires and data processing using double logistic regression analysis. Stunting is influenced by the length of the birth body $(\mathrm{OR}=3.14$; CI $95 \%=2.42$ to $3.86 ; \mathrm{p}=<0.0001)$, breastfeeding $(\mathrm{OR}=2.31$; $\mathrm{CI} 95 \%=1.69$ to $2.93 ; \mathrm{p}=<0.0001)$ and history of infectious diseases $(\mathrm{OR}=2.26$; $\mathrm{CI} 95 \%=1.61$ to $2.91 ; \mathrm{p}=<0.0001)$. Birth weight has no effect on stunting events $(\mathrm{OR}=1$; CI $95 \%=0.32$ to $1.68 ; \mathrm{p}=0.004)$. The incidence of stunting increases with less birth length, unsy exclusive breastfeeding and the absence of a history of infectious diseases in toddlers.
\end{abstract}

Keywords : Birth Weight, Birth Length, Exclusive Breastfeeding, History Of Infectious Diseases, Stunting

Received September 25, 2020; Revised October 19, 2020; Accepted October 28, 2020 


\section{STRADA Jurnal Ilmiah Kesehatan}

DOI: $10.30994 /$ sjik.v9i2.453

ISSN: 2252-3847 (print); 2614-350X (online)

Vol.9 No.2 November 2020 Page.1121-1127

\section{BACKGROUND}

Stunting is one of the forms of malnutrition often faced by developing countries. About $65 \%$ of infant deaths are due to some form of malnutrition and malnutrition representing one-third of the disease burden of children and mothers (Adeela \& Seur, 2016). Indonesia is one of the developing countries that has a high prevalence of stunting which is from 88 countries in the world ranked the fifth highest with cases of stunting (Unicef, 2013).

Riskesdas in 2018 in Indonesia the prevalence of stunting events is 30.8\%. Stunting is considered a severe public health problem when the prevalence of stunting is in the range of 30-39 percent. This shows that Indonesia is experiencing severe public health problems in the case of stunting toddlers. Stunting in Nganjuk Regency in 2018 ranked 9th in East Java at $16.1 \%$. (Dinkes Nganjuk, 2019).

Postnatal factors play an important role in stunting events. Studies in developing countries have shown that stunting depends on the condition of the region's population. (Kinyoki et al, 2016). Stunting leads to subimum growth and development (Perkins et al., 2017). Stunting also increases the global public health burden which accounts for $45 \%$ of all infant deaths (Cruz et al, 2017). Other impacts of stunting are disease, reduced intelligence and productivity (Trihono et al, 2015)

Stunting is a very important issue so community-based interventions must be formulated and implemented to improve children's health (Akombi, 2017). Indonesia conducted a national movement of nutrient awareness in order to accelerate nutritional improvement in the first 1000 days of life (Ministry of Health, 2012).

Researchers examined postnatal factors that influenced stunting events in toddlers in Nganjuk Regency of East Java Province. The purpose of this study is to clarify the effect of postnatal factors on stunting events in toddlers in Nganjuk District.

\section{METHODS}

The design of this study uses observational analytical research with case control design. Research site in Nganjuk Regency from May 15 to June 15, 2020. A sample of 450 toddlers was selected using fixed disease sampling which included a case group of 150 toddlers with stunting and a control group of 300 normal toddlers who were not in stunting, wasting and overweight conditions. The independent variables of this study are birth weight, birth length, exclusive breastfeeding and history of infectious diseases, while dependent variables research stunting cases. Data collection tools use questionnaires and data processing using logistics regression analysis. Researchers pay attention to the ethics of research, namely the granting of inform consent, anonymity and confidentiality to maintain the confidentiality of information provided by the study subjects. Ethichal clearance issued by STRADA Indonesia Institute of Health Sciences with Number:1983/KEPK/V/2020.

\section{RESULTS}

The sample count in the study was 450 toddlers with details of 150 stunting toddlers and 300 normal toddlers who were not in stunting, wasting and overweight conditions. 


\section{STRADA Jurnal Ilmiah Kesehatan}

DOI: $10.30994 /$ sjik.v9i2.453

ISSN: 2252-3847 (print); 2614-350X (online)

Vol.9 No.2 November 2020 Page.1121-1127

1. Univariate Analysis

Table 1. The Results of Univariate Analysis

\begin{tabular}{lcc}
\hline \multicolumn{1}{c}{ Variable } & n & \% \\
\hline Stunting & & \\
Yes & 150 & 33.33 \\
No & 300 & 66.67 \\
Birth Weight & & \\
$<2500$ gram & 140 & 31.11 \\
$\geq 2500$ gram & 310 & 68.89 \\
Birth Length & & \\
$<48 \mathrm{~cm}$ & 165 & 36.67 \\
$\geq 48 \mathrm{~cm}$ & 285 & 63.33 \\
Exclusive Breastfeeding & & \\
Yes & 269 & 59.78 \\
No & 181 & 40.22 \\
History of Infectious Diseases & & \\
Yes & 223 & 49.56 \\
No & 227 & 50.44 \\
\hline
\end{tabular}

The results of the univariate analysis are shown in table 1 . Table 1 shows the number of respondents having a birth weight $\geq 2500 \mathrm{~g} 310$ (68.89\%). Number of respondents with birth length $\geq 48 \mathrm{~cm} 285$ (63.33\%). The number of respondents who received breast milk exclusively was $269(59.78 \%)$. The number of respondents who did not have a history of infection over the last 6 months was $227(50.44 \%)$

\section{Bivariate Analysis}

Table 2. The Results of Bivariate Analysis on the Risk Factors of Stunting in Toddlers

\begin{tabular}{|c|c|c|c|c|c|c|c|c|}
\hline \multirow{3}{*}{$\begin{array}{c}\text { Independent } \\
\text { Variables }\end{array}$} & \multicolumn{4}{|c|}{ Stunting } & \multirow[t]{3}{*}{ OR } & \multicolumn{2}{|c|}{$95 \% \mathrm{CI}$} & \multirow[t]{3}{*}{$p$} \\
\hline & \multicolumn{2}{|c|}{$\begin{array}{c}\text { Yes } \\
(n=150)\end{array}$} & \multicolumn{2}{|c|}{$\begin{array}{c}\text { No } \\
(\mathbf{n}=\mathbf{3 0 0})\end{array}$} & & Lower & Upper & \\
\hline & $\mathbf{n}$ & $\%$ & $\mathbf{n}$ & $\%$ & & Limit & Limit & \\
\hline \multicolumn{9}{|l|}{ Birth Weight } \\
\hline$<2500 \mathrm{~g}$ & 69 & 49.29 & 71 & $\begin{array}{c}50.7 \\
1\end{array}$ & 2.75 & 1.81 & 4.17 & $<0.0001$ \\
\hline$\geq 2500 \mathrm{~g}$ & 81 & 26.13 & 229 & $\begin{array}{c}73.8 \\
7\end{array}$ & & & & \\
\hline \multicolumn{9}{|l|}{ Birth Length } \\
\hline$<48 \mathrm{~cm}$ & 96 & 58.18 & 69 & $\begin{array}{c}41.8 \\
2\end{array}$ & 5.95 & 3.88 & 9.13 & $<0.0001$ \\
\hline$\geq 48 \mathrm{~cm}$ & 54 & 18.95 & 231 & $\begin{array}{c}81.0 \\
5\end{array}$ & & & & \\
\hline \multicolumn{9}{|l|}{$\begin{array}{l}\text { Exclusive } \\
\text { Breastfeeding }\end{array}$} \\
\hline Yes & 47 & 17.47 & 222 & $\begin{array}{c}82.5 \\
3\end{array}$ & 6.24 & 4.05 & 9.60 & $<0.0001$ \\
\hline No & 103 & 56.91 & 78 & $\begin{array}{c}43.0 \\
9\end{array}$ & & & & \\
\hline Infection Disease & & & & & & & & \\
\hline
\end{tabular}




\section{STRADA Jurnal Ilmiah Kesehatan}

DOI: $10.30994 /$ sjik.v9i2.453

ISSN: 2252-3847 (print); 2614-350X (online)

Vol.9 No.2 November 2020 Page.1121-1127

\begin{tabular}{ccccccccc}
\hline Yes & 116 & 52.02 & 107 & & 6.15 & 3.93 & 9.65 & $<0.0001$ \\
& & & & 47.9 & & & & \\
No & 34 & 14.98 & 193 & 85.0 & & & & \\
& & & \multicolumn{7}{c}{$\begin{array}{c}2 \\
\end{array}$} & & & & & \\
\hline
\end{tabular}

The data was analyzed by Chi-squared to observe the relationship between birth weight, birth length, exclusive breastfeeding and a history of infectious diseases by stunting. The results of the bivariate analysis can be seen in table 2

\section{Multivariate Analysis}

Table 3. The Results of a Multiple Logistic Regression Analysis on the Risk Factors of Stunting in Toddlers

\begin{tabular}{lcccc}
\hline \multirow{2}{*}{ Independent Variables } & \multirow{2}{*}{ OR } & \multicolumn{2}{c}{ 95\% CI } & \multirow{2}{*}{ p } \\
\cline { 3 - 4 } & & Lower Limit & Upper Limit & \\
\hline Birth Weight & 1 & 0.32 & 1.68 & 0.004 \\
Birth Length & 3.14 & 2.42 & 3.86 & $<0.0001$ \\
Exclusive Breastfeeding & 2.31 & 1.69 & 2.93 & $<0.0001$ \\
History of Infectious Diesease & 2.26 & 1.61 & 2.91 & $<0.0001$ \\
\hline
\end{tabular}

The results of the multivariate analysis using double logistic regression can be seen in bell 3 . Table 3 shows that there is a relationship between the length of the birth body $<48 \mathrm{~cm}$, not providing exclusive breast milk and the absence of a history of infectious diseases with the incidence of stunting in toddlers. As for the birth weight of 2500 grams there is no influence on stunting events in toddlers. Table 3 shows that the length of the birth body $(\mathrm{OR}=3.14$; CI $95 \%=2.42$ to $3.86 ; \mathrm{p}=<0.0001)$, breastfeeding $(\mathrm{OR}=2.31 ; \mathrm{CI} 95 \%=1.69$ to $2.93 ; \mathrm{p}=<0.0001)$ and history of infectious diseases (OR=2.26; CI 95\%=1.61 to 2.91; $\mathrm{p}=<0.0001)$. Birth weight has no effect on stunting events $(\mathrm{OR}=1 ; \mathrm{CI} 95 \%=0.32$ to 1.68 ; $\mathrm{p}=0.004)$.

\section{DISCUSSION}

\section{The Effect of Birth Weight on the Incidence of Stunting}

The results of the analysis showed no link between birth weight to stunting events. $(\mathrm{OR}=1 ; \mathrm{CI} 95 \%=0.32$ to $1.68 ; \mathrm{p}=0.004)$. The results of this study are in line with research conducted by Ni'mah K \& Nadhiroh S.R which stated that there is no relationship between birth weight and the incidence of stunting in toddlers $(\mathrm{OR}=1$; CI $95 \%=0.23$ to $4.37 ; p=1)$. Birth weight in this study does not show a link can be found in other factors such as inadequacy of nutritional intake, infection and the environment. If in the first 6 months the toddler can improve his nutritional status then there is a possibility of height becoming normal and avoiding stunting at a later age.

\section{The Effect of Birth Length on the Incidence of Stunting}

The results of the analysis showed that there was a gap between the length of the birth body against stunting events and statistically significant. Infants who have a match height of $<48 \mathrm{~cm}$ will increase the likelihood of stunting from infants who have a body length $\geq 48 \mathrm{~cm}(b=4.17$; CI $95 \%=2.19$ to $6.15 ; \mathrm{p}=<0.0001)$. The results of this study are in line with research conducted by Indriyani $\mathrm{E}$ et al with the results $\mathrm{b}=2.13$; $95 \% \mathrm{CI}=$ 0.95 to $3.31 ; \mathrm{p}<0.001$. Setyaningrum et al. (2017) conducting research with the result of every addition of $1 \mathrm{~cm}$ PB born will increase the growth of children according to TB/U by $0.21(b=0.21$; CI $95 \%=0.12$ to $0.30 ; p<0.001)$. This study agrees with Indriani et al 


\section{STRADA Jurnal Ilmiah Kesehatan}

DOI: $10.30994 /$ sjik.v9i2.453

ISSN: 2252-3847 (print); 2614-350X (online)

Vol.9 No.2 November 2020 Page.1121-1127

(2018) that birth length affects stunting events 4.17 times the occurrence of stunting in toddlers. The length of the birth body is one of determinants of the child's growth and development. According to Islam et al (2018 the length of birth control has a significant relationship with stunting. If the birth length measurement is done correctly, it can identify early toddlers who are at risk of stunting

\section{The Effect of Exclusive Breastfeeding on Stunting}

The results of the analysis showed that there was an influence between exclusive breastfeeding on stunting events and statistically significant. Toddlers who do not get breast milk will exclusively increase the likelihood of stunting events than toddlers who get exclusive breast milk (OR=2.31; CI 95\%=1.69 to $2.93 ; \mathrm{p}=<0.0001)$. The results of this study are in line with research conducted by Budiastutik I \& Nugraheni SA (2018) which stated that exclusive breastfeeding can decrease stunting in toddlers in Indonesia. Exclusive breastfeeding improves the immune system in the body. So that toddlers are not susceptible to infectious diseases

\section{The Effect of History of Infectious Diesease on the Incidence of Stunting}

The results of the analysis showed that there was an influence between the administration of the history of infectious diseases on stunting events and statistically significant. Toddlers who have a history of infectious diseases such as diarrhea, pneumonia and breathing over the past 6 months will increase the likelihood of stunting events $(\mathrm{OR}=2.26$; CI $95 \%=1.61$ to $2.91 ; \mathrm{p}=<0.0001))$. This study is in line with Sajalia et al's research that the history of infectious diseases can increase the incidence of stunting in toddlers $(b=3.70 ; 95 \% \mathrm{CI}=0.84$ to $6.56 ; \mathrm{p}=0.011)$. A similar study conducted by Dewi \& Widari (2018) stated that the history of infectious diseases increased the incidence of stunting 3.07 times. Safitri, C.A. \& Nindya, T.S. (2017) states diarrhea is an infectious disease that often occurs in toddlers. This research is in line with a study by Batiro et al. (2017), which stated that diarrhea has a relationship with stunting because when toddlers experience diarrhea, they will lose fluids and appetite and absorption disorders. In addition, respiratory tract infections are also a risk factor for stunting.

\section{CONCLUSION}

Stunting in toddlers is affected by birth length, exclusive breastfeeding and a history of infectious diseases. The length of the birth body of $48 \mathrm{~cm}$ will increase the incidence of stunting in toddlers. Toddlers who do not get exclusive breast milk will increase the incidence of stunting. The history of infectious diseases suffered by toddlers will increase the incidence of stunting in toddlers. Birth weight does not affect stunting events in toddlers. Strong nutrition during toddlerhood one of them is exclusive breast milk for the first 6 months and breast milk-supporting foods will increase the endurance of the body so that toddlers are not easily exposed to infection and normal toddler growth so that stunting events will decrease.

\section{REFERENCES}

Adeela A. \& Seur K. (2016). Impact Of Maternal Socio-Economic Determinants On Early Childhood Stunting In Maldives: An Analysis Of Maldives Demographic Health Survey. Internasional Journal of Scientific \& Technology Research. 5:190-200

Akombi B.J., Agho K.E., Hall J.J., Wali N., Renzaho A.M.N., Merom D. (2017). Stunting, Wasting and Underweight in Sub-Saharan Africa: A Systematic Review. 


\section{STRADA Jurnal Ilmiah Kesehatan}

DOI: $10.30994 /$ sjik.v9i2.453

ISSN: 2252-3847 (print); 2614-350X (online)

Vol.9 No.2 November 2020 Page.1121-1127

International Journal of Environmental Research and Public Health. 14(8). doi: 10.3390/ijerph14080863

Batiro B., Demissie T., Halala Y., Anjulo A.A. (2017). Determinants of Stunting Among Children Aged 6-59 Months at Kindo Didaye woreda, Wolaita Zone, Southern Ethiopia: Unmatched case control study. PloS ONE. 12(12). https://doi.org/10.1371/journal.pone. 0189106.

Budiastutik I. \& Nugraheni S.A. (2018). Determinants of Stunting in Indonesia: A Review Article. International Journal Of Healtcare Research. 1 (2): 43-49

Cruz L.M.G, Azpeiti G.G., Suarez D.R., Rodriquez A.S., Ferrer J.F.L., Serra M.L. (2017). Factors Associated with Stunting among Children Aged 0 to 59 Months from the Central Region of Mozambique. Nutriens Journal. 1-16, doi:10.3390/nu9050491

Dewi \& Widari (2018). Hubungan Berat Badan Lahir Rendah dan Penyakit Infeksi dengan Kejadian Stunting pada Baduta di Desa Maron Kidul Kecamatan Maron Kabupaten Probolinggo. Jurnal Amerta Nutricion. 373-381. doi:10.2473/amnt.v.2i4.2018

Husniyati S, Dewi Y.L.R., Murti B. (2018). Life Course Epidemiology on the Determinants of Stunting in Children Under Five in East Lombok, West Nusa Tenggara, 3(4): 242-251. doi.org/10.26911/thejmch.2018.03.04.01

Indriani D., Dewi Y.L.R., Murti B., Qadrijati I. (2018). Prenatal Factors Associated with the Risk of Stunting: A Multilevel Analysis Evidence From Nganjuk, East Java. Journal of Maternal and Child Health, 3(4): 294-300.

doi.org/10.26911/thejmch.2018.03.04.07

Indriyani E., Dewi Y.L.R., Murti B., Salimo H. (2018). Biopsychosocial Determinants of Stunting in Children Under Five: A Path Analysis Evidence from the Border Area West Kalimantan. Journal of Maternal and Child Health, 3(2): 146-155. doi.org/10.26911/thejmch.2018.03.02.07

Islam M.M., Sanin K.I., Mahfuz M., Ahmed A.M.S., Mondal D., Haque R., Ahmed T. (2018). Risk factors of Stunting among Children Living in an Urban Slum of Bangladesh: Findings of a Prospective Cohort Study. BMC Public Health. 18(197). doi: 10.1186/s12889-018-5101-x.

Kementerian Kesehatan RI. 2012. Pedoman Pelaksanaan Stimulasi, Deteksi dan Intervensi Dini Tumbuh Kembang Anak Ditingkat Pelayanan Kesehatan Dasar. Jakarta.

Kinyoki D.K, Kandala N.B, Manda S.O., Krainski E.T., Fugltad G.A., Moloney G.M., Berkley J.A., Noor M.A. (2016). Assesing Morbidity and Correlates of Wasting and Stunting among Children in Somalia using Cross-sectional Household Surveys 2007-2010. BMJ. 6:1-9. doi: 10.1136/bmjopen-2015-009854 


\section{STRADA Jurnal Ilmiah Kesehatan}

DOI: $10.30994 /$ sjik.v9i2.453

ISSN: 2252-3847 (print); 2614-350X (online)

Vol.9 No.2 November 2020 Page.1121-1127

Ni'mah K, Nadhiroh SR. (2015). Faktor yang Berhubungan dengan Kejadian Stunting pada Balita. Departemen Gizi Keshatan Fakultas Kesehatan Masyarakat Universtitas Airlangga.

Perkins J.M., Kim R., Krishna A., Mc Govern M., Aguayo V.M., Subramanian S.V. (2017). Understanding the association between stunting and child development in low- and middle income countries: Next steps for research and intervention. Social Science \& Medicine. 193: 101-109.

https://doi.org/10.1016/j.socscimed.2017.09.039

Safitri, C.A. \& Nindya, T.S. (2017). Hubungan Ketahanan Pangan dan Penyakit Diare dengan Stunting pada Balita 13-48 Bulan di Kelurahan Manyar Sabrangan Surabaya. Jurnal Amerta Nutritama, 1(2), 52-61. doi:10.20473/amnt.v1i2.2017.5261

Setyaningrum T.C.W., Murti B., Indarto D., (2017). Biopsychosocial Factors Associated with Child Growth at Ngembal Kulon Community Health Center, Kudus. Journal of Epidemiology and Public Health. 2(2):130-140. doi.org/10.26911/jepublichealth

Trihono, Atmarita, Tjandrarini D.H., Irawati A., Utami N.H, Tejayanti T. (2015). Pendek (Stunting) di Indonesia, masalah dan solusinya. Jakarta: Lembaga Penerbit Balitbangkes

UNICEF (2013). Improving Child Nutricion, the Achievable Imperative for Global Progress. New York: United Nations Children's Fund 